\title{
COMPARATIVE ANALYSIS OF TRAVEL COSTS ON TOLL ROADS AND NON-TOLL ROADS FOR CITY CENTER ACCESS
}

\author{
Lambang Basri Said \\ Master Program in Civil Engineering, \\ Universitas Muslim Indonesia Makassar, Indonesia \\ Ilham Syafey \\ Master Program in Civil Engineering, \\ Universitas Muslim Indonesia Makassar, Indonesia \\ Qadriathi Dg Bau \\ Civil Department of Engineering Faculty, \\ Universitas Negeri Makassar, Indonesia \\ *Corresponding Author Email: lambangbasri.said@umi.ac.id
}

\begin{abstract}
The Mamminasata Urban Area which is centered in Makassar City has a fivesection crossroads at the north gate of the city, where two of which, the Sutami toll and Perintis Kemerdekaan non-toll road sections lead to the city center while the gate is accessed by 18 districts and all provinces in Sulawesi. As alternative roads, the two is generally described as follows: The distance of the gate to the city by the toll road is $17 \mathrm{~km}$ while that of by Jalan Perintis Kemerdekaan is $24 \mathrm{Km}$ or $7 \mathrm{~km}$ longer than the toll road. The toll road is smooth during the day while the Perintis Kemerdekaan nontoll road section is congested at the peak hours in the morning, afternoon and evening with the potential resulting in far different costs and travel time. The results of the survey indicate 2: 5 in average ratio suggesting that 5 vehicles enter the city center through Perintis Kemerdekaan Non-Toll Road while 2 vehicles opt for Sutami Toll Road. This study was aimed at (1) comparing the Vehicle Operating Costs (VOC) from and to the city center through toll roads or non-toll roads, and (2) analyzing the tendency of the number of travellers to choose through toll roads and non-toll roads based on their orientation to the unit of cost to incur. The mathematical and statistical analysis process was done by considering all components of fixed and variable costs. The analysis also considers the use of the elemental mode of driving mode, the average speed model and the translog and Cobb-Douglas models. The results obtained illustrate that the value of vehicle operating costs derived from the two road sections amount to Rp. 25,462 and Rp. 25,500 suggesting insignificant difference. Despite similar travel cost between the two, the toll road is considered more beneficial in terms of the value of time and energy for motorists travelling to the city center of Makassar.
\end{abstract}


Keywords: Comparison, Cost, Time, VOC, Makassar City.

Cite this Article: Lambang Basri Said, Ilham Syafey and Qadriathi Dg Bau, Comparative Analysis of Travel Costs on Toll Roads and Non-Toll Roads for City Center Access. International Journal of Civil Engineering and Technology, 11(1), 2020, 242-253.

http://iaeme.com/Home/issue/IJCIET?Volume=11\&Issue $=1$

\section{INTRODUCTION}

The role of transportation, especially land transportation, is definitely urgent, especially in the aspect of the movement of people and goods to destination and it increases economic growth in the city and its surrounding areas. Along with the growth of population and the number of vehicles, especially four-wheeled vehicles, impacts occur on various things including road capacity, parking spaces and congestion, toll roads which are paid and not free are constructed by related agencies as an alternative. Morever, traffic engineering is also carried out on nontoll road sections aimed at smoothing movements and minimizing rates of accidents.

In general, every city in major cities in the world is always accessed by toll roads and nontoll roads connecting to the city center. In Makassar, for example, as a metro city, the Mamminasata urban area has two city entry gates, the north gate of the city that serves 18 cities and districts in South Sulawesi, and the east gate that serves 6 districts / cities. The north gate of Makassar City has a five-section crossroads connecting the city gate, the toll road, the road section beside toll road, Perintis Kemerdekaan road section, and the road leading to the airport. The level of congestion on non-toll road intersections is generally quite high at any times despite the operation of underpass since 2017 that enables better flow of vehicles.

General description of the two alternative roads to the city suggests that Toll Road is 17 $\mathrm{Km}$ in distance with are quite good and smooth road condition. On the other hand, Perintis Kemerdekaan Non-toll Road Section which is $24 \mathrm{Km}$ long is varied in condition and width to serve as the main road and has spots of traffic congestion. Along the road, there are various centers of public activities such as centers of trading, settlement, education and industrial areas.

Calculation related to travel time variability will then add far different costs for different routes, affecting the choice of travel routes, and travel destination orientation [1]. When the tendency of potential toll road users and non-toll road users is compared, ideally toll roads are more desirable because of its various advantages, However, non-toll road users generally higher those of toll roads in Makassar City. Initial observations of the tendency of travellers at the north gate of the city with two alternative choices to the city center resulted in a comparison of 2: 5, meaning that two vehicles enter the Toll road while five vehicles opt for Perintis Kemerdekaan non toll road. It therefore raises a temporary perception on why travellers from outside the city tend to enter the high level of congestion compared to quite smooth traffic in toll road. Possible considerations are as follows:

- Non-toll road section is choosen because the travelers plan for stopover at several activity centers.

- Non-toll roads do not incur real costs compared to toll roads as suburb people tend to value real money (toll tariffs) non-real money such as Vehicle Operating Costs (VOC)

- The choice of travelers for the Toll Road is due to the smoothness and time consideration.

Transportation is indeed inseparable from the financing factor, the higher the level of congestion, the greater the costs absorbed through vehicle operating costs, In this regard, not 
all travelers are aware of the vehicle operating costs absorbed both during smooth condition or congestion, as a result, travelers are likely to avoid toll rates which becomes the reasons for them to opt for non-toll roads. In contrast to developed countries, travellers are more interested to use toll roads if they prioritize the value of time and access.

The fundamental problem in this paper is how to compare the interests of the two alternative hub users to the city center and how to compare the travel costs of the two. If it is found that non-toll roads are higher in cost, dissemination shall be done various media to make sure that the public are aware of the cost between the two alternatives. This study has objectives as follows:

1. To analyze the tendency of the number of users of toll roads and non-toll roads based on orientation to the unit of cost incurred.

2. To review the comparison of travel costs between toll roads and non-toll roads as an access to the center of the Mamminasata urban area in Makassar City

\section{RESEARCH METHODS}

\subsection{Analysis of Vehicle Operating Cost Components}

Vehicle operating costs are composed of various cost components. To calculate travel costs from a mode of transportation, costs are broken into fixed costs, variable costs, and total costs. After classifying the cost into fixed cost and variable cost components, cost component is subdivided into cost elements, subsequently, the cost elements are subdivided into the next level elements. This process resembles the work breakdown structure in a project.

Private car transportation consists of depreciation cost and taxes. Depreciation can be determined by purchase costs, salvage value, interest rates and age of vehicle usage. While taxes and insurance can be determined by the respective calculation methods. The results of all these fixed cost elements are added up to achieve the total fixed costs in unit of Rp / year [2].

Variable costs in the use of private car transportation consist of costs of fuel, maintenance, lubricant, spareparts, parking, and unexpected costs. This paper includes the cost elements which cover depreciation costs, vehicle taxes, fuel costs, lubricant costs, spareparts costs, and tire usage costs. While other costs such as insurance, parking, unexpected costs, and others are excluded. All elements of this variable cost are summed to get the total variable cost in unit of $\mathrm{Rp} / \mathrm{km}$.

To get total costs, the units of total fixed costs and total variable costs must be equalized. By fixing the vehicle mileage within one year, the total fixed costs can be made into unit of $\mathrm{Rp} / \mathrm{km}$ and then added to the total variable costs for the total vehicle operating costs. [3]

Table 1. Component of VOC

\begin{tabular}{|c|c|}
\hline Fixed Costs & Variable Costs \\
\hline Depreciation & Fuel \\
\hline Taxes & Spareparts \\
\hline & Oil \\
\hline & Tire Usage \\
\hline
\end{tabular}

\subsection{Data Collection}

In the analysis of vehicle operating costs for private car vehicles, various data are classified into primary data and secondary data. Secondary data were obtained from various sources such as car manufacturers, relevant agencies, and other studies related the operating costs of private vehicles. Secondary data include vehicle characteristics, unit costs, and traffic 
characteristics, whereas primary data are gathered by conducting surveys and measurements, especially on average speed of vehicles during peak hours, including pie peak time, afternoon peak and afternoon peak time. Another common method is interviews or questionnaires with users or vehicle owners regarding costs during smooth and traffic times, but this method is less accurate in the cost calculation. This method initiates with designing questionnaire instruments for expected data. The primary data consist of vehicle operating characteristics such as mileage, travel time, average speed, and vehicle price and annual vehicle tax.

\subsection{Calculation of Cost Units}

In calculating vehicle operating costs, cost units in the form of units of money for vehicle use are used. To fixed costs, which are not affected by vehicle use, the unit cost used is Rp / year which will then be converted to $\mathrm{Rp} / \mathrm{km}$ while the unit cost used is $\mathrm{Rp} / \mathrm{km}$ for variable costs. After the cost units are fixed, a calculation tool was made in the form of a spreadsheet program for data processing. The data for program input shall be found by considering various factors using the method of vehicle operating costs.

Depreciation calculation requires data such as the purchase price of the vehicle, the salvage value, the interest rate, and the age of vehicle usage [4]. The purchase price of the vehicle can be obtained from the vehicle manufacturer added with administrative costs gained from the relevant agencies. The salvage value can be determined by the sale value of similar vehicles after a certain age of usage. In this study, five years was stated as the lifespan for private cars. Average depreciation calculation was obtained from the samples of some brands which are three brands with $1500 \mathrm{cc}$ engine capacity. This depreciation calculation is converted from $\mathrm{Rp} /$ year to $\mathrm{Rp} / \mathrm{km}$.

\subsubsection{Calculation of Variable Costs}

Variable costs of vehicle operating costs refers to the costs depending to the vehicle usage. Variable costs of vehicle operating costs include fuel costs, lubricant costs, spareparts costs, and tire costs. This variable cost has a unit of $\mathrm{Rp} / \mathrm{km}$ and is influenced by various things. In calculating the costs, this study uses variations in distance and average speed of the vehicle. The formulas and are obtained from VOC calculation.

\subsubsection{Fuel Consumption Costs}

To calculate the fuel costs, it is necessary to determine the average fuel consumption of the vehicle in liters / $\mathrm{km}$. The unit price of fuel is $\mathrm{Rp}$. 6,450 / liter for premium fuel, based on which the fuel cost can be calculated. Fuel consumption is affected by vehicle speed. The optimum speed results in fuel consumption between $45 \mathrm{~km} / \mathrm{hr}$ to $65 \mathrm{~km} / \mathrm{hr}$ [5]. Below is the formula to calculate the fuel costs: [6]

$$
\mathrm{BiBBMj}=\mathrm{KBBMi} \times \mathrm{HBBMj}
$$

In which:

$$
\begin{aligned}
& \mathrm{BiBBMj}=\text { Fuel Consumption Costs for vehicle type } \mathrm{i} \text { in rupiah } / \mathrm{km} \\
& \mathrm{KBBMi}=\text { Fuel Consumption for vehicle type } \mathrm{i} \text { in rupiah } / \mathrm{km} \\
& \mathrm{HBBMj}=\text { Fuel price for BBMj type in rupiah / liter (Premium is at Rp.6,450/ lt) } \\
& \mathrm{I} \quad=\text { Sedan and sedan class type (SD) } \\
& \mathrm{J} \quad=\text { Premium fuel type (PRM) }
\end{aligned}
$$

\subsubsection{Oil Consumption Costs}

The calculation of Oil Consumption Costs does not distinguish average speed. The formula used in the calculation of oil consumption costs is as follows [7]

$$
\mathrm{OHKi}=\mathrm{KPOi}: \text { JPOi }
$$


In which:

$\mathrm{OHKi}=$ Oil lost due to contamination in liters $/ \mathrm{km}$

KPOi = Oil capacity in liters

JPOi $=$ Distance of oil change

and

$$
\mathrm{KOi}=\mathrm{OHKi}+\mathrm{OHOi} \times \mathrm{KBBMi}
$$

In which:

KOi = Oil consumption for vehicle type $\mathrm{i}$ in liters $/ \mathrm{km}$

$\mathrm{OHKi}=$ Oil lost due to contamination in liters $/ \mathrm{km}$

OHOi $=$ Oil lost due to operations in liters $/ \mathrm{km}$

$\mathrm{KBBMi}=$ Fuel consumption in liters $/ \mathrm{km}$

$$
\mathrm{BOi}=\mathrm{KOi} \times \mathrm{Hoj}
$$

In which:

BOi = Oil consumption costs for vehicle type $\mathrm{i}$ in rupiah $/ \mathrm{km}$

KOi = Oil consumption for vehicle type $\mathrm{i}$ in liters $/ \mathrm{km}$

$\mathrm{HOj}=$ type $\mathrm{j}$ oil in rupiah $/$ liter

$\mathrm{i} \quad=$ Vehicle type

$\mathrm{j} \quad=$ Oil type $($ Enduro $4 \mathrm{~T})$

\subsubsection{Spareparts Costs}

Spareparts consumption costs are obtained with the formula below: [2]

$$
\mathrm{Pi}=\left(\varphi+\gamma_{1} \times \mathrm{IRI}\right) .(\mathrm{KJTi} / 100000)^{\gamma}
$$

In which:

$\mathrm{Pi} \quad=$ Spareparts consumption of vehicle type $\mathrm{i}$ per million kilometers

$\varphi \quad=$ Constant

$\boldsymbol{\gamma}_{1}, \boldsymbol{\gamma}_{\mathbf{2}}=$ Parameter coefficient

IRI $=$ Road roughness in $\mathrm{m} / \mathrm{km}(5 \mathrm{~m} / \mathrm{km}=5$ is used $)$

$\mathrm{KJTi}$ cumulative mileage of vehicle type $\mathrm{i}$ in $\mathrm{km}$

$\mathrm{I} \quad=$ type of Vehicle type

$$
\mathrm{BPi}=\mathrm{Pi} \times \mathrm{HKBi} / 1000000
$$

In which:

Bpi = Vehicle maintenance costs for vehicle type $\mathrm{i}$ in rupiah $/ \mathrm{km}$

$\mathrm{HKBi}=$ Average price of new vehicles for vehicle type $\mathrm{i}$ in rupiah

$\mathrm{Pi} \quad=$ Relative value of the spareparts costs against price of new vehicles for vehicle type $\mathrm{i}$

$\mathrm{i} \quad=$ Vehicle type

\subsubsection{Tire Consumption Costs}

Tire consumption for vehicles uses equation (7) Tire consumption costs are calculated with the formula (9). Below are the formulas used to calculate tire consumption costs: [2]

$$
\mathrm{KBi}=\chi+\delta_{1} \times \mathrm{IRI}+\delta_{2} \times \mathrm{TTR}+\delta_{3} \times \mathrm{DTR}
$$

In which:

$\mathrm{KBi}=$ Tire consumption for vehicle type $\mathrm{i}$

$\mathrm{X}=$ Constant 
$\delta_{1} . \delta_{3}=$ Coefficient

TTR = Average grade and slope

DTR = Average degree of bend

$$
\mathrm{BBi}=\mathrm{KBi} \times \mathrm{HBj} / 1000
$$

In which:

$\mathrm{BBi}=$ Tire consumption costs for vehicle type $\mathrm{i}$

$\mathrm{KBi}=$ Tire consumption for vehicle type $\mathrm{i}$

$\mathrm{HBj}=$ Price of new type $\mathrm{J}$ tire in rupiah $(600,000,-)$

$\mathrm{i} \quad=$ Vehicle type

$\mathrm{j} \quad=$ Tire type

\subsubsection{Factors That Affect Costs}

Travel costs are influenced by various factors such as vehicle, road, traffic, and human. Vehicle speed is a factor used for simulation, which is affected by traffic conditions, fuel consumption, speed and distance variations [2]

\section{RESULTS AND DISCUSSION}

\subsection{Fixed costs}

The calculation of fixed costs in Vehicle Operating Costs (VOC) includes depreciation calculation using the straight line method and the tax used refers to the annual tax of Rp 2,250,000.-

\subsubsection{Depreciation}

The calculation uses the price of a 5-year old used vehicle as follows:

a. Annual depreciation fee $=$ annual depreciation cost $/$ mileage

b. Vehicle mileage $=6,000 \mathrm{~km} /$ year

c. Depreciation fee per $\mathrm{km}=(\mathrm{Rp} .3,565,000 /$ year $) /(6,000 \mathrm{~km} /$ year $)$

$=$ Rp. $594.17-/ \mathrm{km}$

d. The length of Perintis Kemerdekaan road section $=11.8 \mathrm{~km}=\mathrm{Rp} .594 .17 \times 11.8$

$$
=\text { Rp. 7,011.17 }
$$

\subsubsection{Vehicle Tax Costs}

The average vehicle tax for private cars is Rp. 2,225,000 per year. This figure shall be converted into $\mathrm{Rp} / \mathrm{km}$ resulted from division by annual mileage.

Tax Cost per $\mathrm{km}=$ annual tax $/$ annual mileage

Vehicle mileage $=6,000 \mathrm{~km} /$ year

Depreciation cost per $\mathrm{km}=($ Rp. 2,225,000 / year $) /(6,000 \mathrm{~km} /$ year $)$

$=$ Rp. $375 / \mathrm{km}$

Table 2. Results of Tax Cost Calculation per km

\begin{tabular}{|c|c|}
\hline $\begin{array}{c}\text { Annual Mileage } \\
(\mathbf{k m})\end{array}$ & $\begin{array}{c}\text { Tax Cost } \\
(\mathbf{R p} / \mathbf{k m}\end{array}$ \\
\hline 6,000 & 3.75 \\
\hline 12,000 & 187.50 \\
\hline 18,000 & 125.00 \\
\hline 24,000 & 93.75 \\
\hline
\end{tabular}




\subsection{Variable Costs}

Variable cost of vehicle operating costs refer cost of which amount depends on the use of vehicles such as fuel, lubricant oil, spareparts, and tires. This variable cost has a unit of Rp. / $\mathrm{km}$ and is influenced by various things in which this study used only variations in vehicle mileage and average speed.

\subsubsection{Fuel Consumption Costs}

Below is the calculation of the fuel cost for a type of private car at an average speed of $15 \mathrm{~km}$ / hour

$$
\begin{aligned}
& \mathrm{KBBMi}(\mathrm{SD})=(\alpha+\beta 1 / \mathrm{VR}+\beta 2 \times \mathrm{VR} 2+\beta 3 \times \mathrm{RR}+\beta 4 \times \mathrm{FR}+\beta 5 \times \mathrm{FR} 2+\beta 6 \\
& \quad \times \mathrm{DTR} \beta 7 \times \mathrm{AR}+\beta 8 \times \mathrm{SA}+\beta 9 \times \mathrm{BK}+\beta 10 \times \mathrm{BK} \times \mathrm{AR}+\beta 11 \times \mathrm{BK} \times \mathrm{SA}) \\
& \quad / 1000 . \\
& =\left(23.78+1,181,2 / 15+0.0037 \times 15^{2}+1,265 \times 2.5+0.634 \times(-2.5)\right. \\
& \quad+0+0+(-0.638) \times 0,01+36.21 \times 0.75+0+0+0) / 1,000 \\
& =132 / 1,000=0.132 \mathrm{liter} / \mathrm{km} \\
& \mathrm{BiBBMj}(\mathrm{SD})=0.132 \text { liter } / \mathrm{km} \times \mathrm{Rp} 6,450,- \\
& \quad=\mathrm{Rp} .851 .96 / \mathrm{km}
\end{aligned}
$$

The calculation of fuel costs for car-type vehicles at an average speed of $20 \mathrm{~km} / \mathrm{h}, 25 \mathrm{~km}$ / h, $30 \mathrm{~km} / \mathrm{h}, 35 \mathrm{~km} / \mathrm{h}$, and $40 \mathrm{~km} / \mathrm{h}$, is presented in Table 3. The following are the calculation results fuel costs at various average speeds:

Table 3. Fuel Costs

\begin{tabular}{|c|c|}
\hline $\begin{array}{c}\text { Average Vehicle } \\
\text { Speed } \\
(\mathbf{k m} / \mathbf{h})\end{array}$ & $\begin{array}{c}\text { Fuel Costs } \\
(\mathbf{R} \mathbf{p} / \mathbf{k m})\end{array}$ \\
\hline 15 & 851.96 \\
\hline 20 & 729.16 \\
\hline 25 & 658.34 \\
\hline 30 & 614.12 \\
\hline 35 & 585.59 \\
\hline 40 & 567.33 \\
\hline 45 & 556.31 \\
\hline 50 & 550.71 \\
\hline 55 & 548.39 \\
\hline 60 & 551.57 \\
\hline 65 & 556.72 \\
\hline 70 & 564.45 \\
\hline
\end{tabular}

\subsubsection{Oil Consumption Costs}

Oil price of Rp 110,000 was used as the basic data, oil capacity of car is 4.0 liters and distance for oil change is $5,000 \mathrm{~km}$ for cars.

Below is the calculation of oil consumption costs:

$$
\begin{aligned}
\text { OHKi } & =\text { KPOi } / \mathrm{JPOi} \\
& =4 \text { liter } / 5,000 \mathrm{~km} \\
& =0.0008 \text { liter } / \mathrm{km} \\
\mathrm{KOi} & =\text { OHKi }+ \text { OHOi } \times \mathrm{KBBMi} \\
& =0.0008 \text { liter } / \mathrm{km}+2,8 \times 10-6 \mathrm{lt} / \mathrm{km} \times \mathrm{lt} / \mathrm{km} \\
& =0.0008 \text { liter } / \mathrm{km}
\end{aligned}
$$


$\mathrm{BOi}(\mathrm{SM})=\mathrm{KOi} \times \mathrm{HOj}$

$$
\begin{aligned}
& =0.0008 \mathrm{lt} / \mathrm{km} \times \text { Rp. } 110,000,- \\
& =\text { Rp. } 88.31 \mathrm{lt} / \mathrm{km}
\end{aligned}
$$

Thus, oil / lubricant consumption cost is Rp. $88.31 \mathrm{lt} / \mathrm{km}$ for all speeds and annual mileage.

\subsubsection{Spareparts Costs}

This annual mileage will be used to estimate cumulative mileage. The following is the calculation of the spareparts costs for vehicles with an annual mileage of $6,000 \mathrm{~km}$.

$$
\begin{aligned}
\mathrm{Pi} & =(-0.69+0.42 \times 5)(15,000 / 100,000)^{0,10} \\
& =1,166 \\
\mathrm{BPi} & =1,166 \times \text { Rp. } 183,450,000,-/ 1,000,000 \\
& =\text { Rp. } 213.97 / \mathrm{km}
\end{aligned}
$$

Table 4 presents the calculation results of spareparts costs for motorbike types for various annual mileage:

Table 4. Spareparts Costs

\begin{tabular}{|c|c|}
\hline $\begin{array}{c}\text { Annual Mileage } \\
(\mathbf{k m})\end{array}$ & $\begin{array}{c}\text { Spareparts Costs } \\
(\mathbf{R} \mathbf{p} / \mathbf{k m})\end{array}$ \\
\hline 6,000 & 213.97 \\
\hline 12,000 & 229.32 \\
\hline 18,000 & 238.81 \\
\hline 24,000 & 245.78 \\
\hline
\end{tabular}

\subsubsection{Tire Consumption Costs}

This calculation uses tire consumption for sedan car and the price of new car tires at Rp. 575,000 as the basis for calculation. Below is the calculation of tire consumption costs for cars:

$$
\begin{gathered}
\mathrm{KBi}(\mathrm{SM})=\chi+\delta 1 \times \mathrm{IRI}+\delta 2 \times \mathrm{TTR}+\delta 3 \times \mathrm{DTR} \\
=-0.01471+0.01489 \times 5+0+0 \\
=0.05974
\end{gathered}
$$

$\mathrm{BBi}(\mathrm{SM})=\mathrm{KBi} \times \mathrm{HBj} / 1000$

$$
\begin{aligned}
& =0.05974 \times \text { Rp. } 575,000,-/ 1000 \\
& =\text { Rp. } 34.35 / \mathrm{km}
\end{aligned}
$$

\subsection{Total Cost Calculation}

Following the identification of the fixed and variable costs of VOC, the total VOC for each variation of speed and annual mileage can be calculated. Below are the results:

For annual mileage (d) 6,000 km and average speed (V) $15 \mathrm{~km} /$ hour

VOC $=$ depreciation + tax + fuel costs + lubricant costs + Spareparts costs + Tire costs

$=594.17+375+851.96+88.31+213.97+34.35$

$=$ Rp. $2,157.76 / \mathrm{km}$

VOC for mileage (d) $6,000 \mathrm{~km}$ and average speed (v) $15 \mathrm{~km} /$ hour with the length of the Perintis Kemerdekaan road along $11.8 \mathrm{~km}$, the VOC value is:

VOC of Perinstis Kemerdekaan Road

$$
\begin{aligned}
& =\text { Rp. } 2,157.76 \times 11.8 \mathrm{~km} \\
& =\text { Rp. } 25,461 .
\end{aligned}
$$


Comparative Analysis of Travel Costs on Toll Roads and Non-Toll Roads for City Center Access

Tables 5 through 9 show the calculation of VOC for annual distances of $6,000 \mathrm{~km}, 12,000$ $\mathrm{km}, 18,000 \mathrm{~km}$ and $24,000 \mathrm{~km}$ with the cost components at an average speed variation of 15 $\mathrm{km} / \mathrm{h}$ to $70 \mathrm{~km} / \mathrm{h}$.

Table 5. VOC Tabulation for mileage of $6,000 \mathrm{~km} / \mathrm{yr}$

\begin{tabular}{|c|c|c|c|c|c|c|c|}
\hline \multicolumn{9}{|c|}{ VOC Component } \\
\hline $\begin{array}{c}\text { Average } \\
\text { Vehicle } \\
\text { Speed } \\
\text { (km/hour) }\end{array}$ & Depreciation & Tax & Fuel & Oil & Spareparts & Tire & $\begin{array}{c}\text { Total } \\
(\text { Rp) }\end{array}$ \\
\hline 15 & 594,17 & 375 & 851,96 & 88,31 & 213,97 & 34,35 & $2.157,76$ \\
\hline 20 & 594,17 & 375 & 729,16 & 88,31 & 213,97 & 34,35 & $2.034,96$ \\
\hline 25 & 594,17 & 375 & 658,34 & 88,31 & 213,97 & 34,35 & $1.964,14$ \\
\hline 30 & 594,17 & 375 & 614,12 & 88,31 & 213,97 & 34,35 & $1.919,92$ \\
\hline 35 & 594,17 & 375 & 585,59 & 88,31 & 213,97 & 34,35 & $1.891,39$ \\
\hline 40 & 594,17 & 375 & 567,33 & 88,31 & 213,97 & 34,35 & $1.873,13$ \\
\hline 45 & 594,17 & 375 & 556,31 & 88,31 & 213,97 & 34,35 & $1.862,11$ \\
\hline 50 & 594,17 & 375 & 550,71 & 88,31 & 213,97 & 34,35 & $1.856,51$ \\
\hline 55 & 594,17 & 375 & 549,39 & 88,31 & 213,97 & 34,35 & $1.855,19$ \\
\hline 60 & 594,17 & 375 & 551,57 & 88,31 & 213,97 & 34,35 & $1.857,37$ \\
\hline 65 & 594,17 & 375 & 556,72 & 88,31 & 213,97 & 34,35 & $1.862,52$ \\
\hline 70 & 594,17 & 375 & 564,45 & 88,31 & 213,97 & 34,35 & $1.870,25$ \\
\hline
\end{tabular}

Table 6. VOC Tabulation for mileage of $12,000 \mathrm{~km} / \mathrm{yr}$

\begin{tabular}{|c|c|c|c|c|c|c|c|}
\hline \multicolumn{7}{|c|}{ VOC Component } \\
\hline $\begin{array}{c}\text { Average } \\
\text { Vehicle } \\
\begin{array}{c}\text { Speed } \\
\text { (km/hour) }\end{array}\end{array}$ & Depreciation & Tax & Fuel & Oil & Spareparts & Tire & $\begin{array}{c}\text { Total } \\
(\mathbf{R p})\end{array}$ \\
\hline 15 & 297,08 & 187,50 & 851,96 & 88,31 & 229,32 & 34,35 & $1.673,17$ \\
\hline 20 & 297,08 & 187,50 & 729,16 & 88,31 & 229,32 & 34,35 & $1.550,37$ \\
\hline 25 & 297,08 & 187,50 & 658,34 & 88,31 & 229,32 & 34,35 & $1.479,55$ \\
\hline 30 & 297,08 & 187,50 & 614,12 & 88,31 & 229,32 & 34,35 & $1.435,33$ \\
\hline 35 & 297,08 & 187,50 & 585,59 & 88,31 & 229,32 & 34,35 & $1.406,80$ \\
\hline 40 & 297,08 & 187,50 & 567,33 & 88,31 & 229,32 & 34,35 & $1.388,54$ \\
\hline 45 & 297,08 & 187,50 & 556,31 & 88,31 & 229,32 & 34,35 & $1.377,52$ \\
\hline 50 & 297,08 & 187,50 & 550,71 & 88,31 & 229,32 & 34,35 & $1.371,92$ \\
\hline 55 & 297,08 & 187,50 & 549,39 & 88,31 & 229,32 & 34,35 & $1.370,6$ \\
\hline 60 & 297,08 & 187,50 & 551,57 & 88,31 & 229,32 & 34,35 & $1.372,78$ \\
\hline 65 & 297,08 & 187,50 & 556,72 & 88,31 & 229,32 & 34,35 & $1.377,93$ \\
\hline 70 & 297,08 & 187,50 & 564,45 & 88,31 & 229,32 & 34,35 & $1.385,66$ \\
\hline
\end{tabular}

Table 7. VOC Tabulation for mileage of $18,000 \mathrm{~km} / \mathrm{yr}$

\begin{tabular}{|c|c|c|c|c|c|c|c|}
\hline \multicolumn{2}{|c|}{ VOC Component } & Onerage \\
$\begin{array}{c}\text { Vehicle } \\
\text { Speed } \\
\text { (km/hour) }\end{array}$ & Depreciation & Tax & Fuel & Oil & Spareparts & Tire & $\begin{array}{c}\text { Total } \\
\text { (Rp) }\end{array}$ \\
\hline 15 & 198.05 & 125 & 851.96 & 88.31 & 213.97 & 34.35 & $1,511.64$ \\
\hline 20 & 198.05 & 125 & 729.16 & 88.31 & 213.97 & 34.35 & $1,388.84$ \\
\hline 25 & 198.05 & 125 & 658.34 & 88.31 & 213.97 & 34.35 & $1,318.02$ \\
\hline 30 & 198.05 & 125 & 614.12 & 88.31 & 213.97 & 34.35 & $1,273.80$ \\
\hline 35 & 198.05 & 125 & 585.59 & 88.31 & 213.97 & 34.35 & $1,245.27$ \\
\hline 40 & 198.05 & 125 & 567.33 & 88.31 & 213.97 & 34.35 & $1,227.01$ \\
\hline 45 & 198.05 & 125 & 556.31 & 88.31 & 213.97 & 34.35 & $1,215.99$ \\
\hline 50 & 198.05 & 125 & 550.71 & 88.31 & 213.97 & 34.35 & $1,210.39$ \\
\hline
\end{tabular}


Lambang Basri Said, Ilham Syafey and Qadriathi Dg Bau

\begin{tabular}{|l|l|l|l|l|l|l|l|}
\hline 55 & 198.05 & 125 & 549.39 & 88.31 & 213.97 & 34.35 & $1,209.07$ \\
\hline 60 & 198.05 & 125 & 551.57 & 88.31 & 213.97 & 34.35 & $1,211.25$ \\
\hline 65 & 198.05 & 125 & 556.72 & 88.31 & 213.97 & 34.35 & $1,216.40$ \\
\hline 70 & 198.05 & 125 & 564.45 & 88.31 & 213.97 & 34.35 & $1,224.13$ \\
\hline
\end{tabular}

Table 8. VOC Tabulation for mileage of $24,000 \mathrm{~km} / \mathrm{yr}$

\begin{tabular}{|c|c|c|c|c|c|c|c|}
\hline \multicolumn{8}{|c|}{ VOC Component } \\
\hline $\begin{array}{l}\text { Average } \\
\text { Vehicle } \\
\text { Speed } \\
\text { (km/hour) }\end{array}$ & Depreciation & Tax & Fuel & Oil & Spareparts & Tire & $\begin{array}{l}\text { Total } \\
\text { (Rp) }\end{array}$ \\
\hline 15 & 148.54 & 93.75 & 851.96 & 88.31 & 213.97 & 34.35 & $1,430.74$ \\
\hline 20 & 148.54 & 93.75 & 729.16 & 88.31 & 213.97 & 34.35 & $1,307.94$ \\
\hline 25 & 148.54 & 93.75 & 658.34 & 88.31 & 213.97 & 34.35 & $1,237.12$ \\
\hline 30 & 148.54 & 93.75 & 614.12 & 88.31 & 213.97 & 34.35 & $1,192.90$ \\
\hline 35 & 148.54 & 93.75 & 585,59 & 88.31 & 213.97 & 34.35 & $1,164.37$ \\
\hline 40 & 148.54 & 93.75 & 567.33 & 88.31 & 213.97 & 34.35 & $1,146.11$ \\
\hline 45 & 148.54 & 93.75 & 556.31 & 88.31 & 213.97 & 34.35 & $1,135.23$ \\
\hline 50 & 148.54 & 93.75 & 550.71 & 88.31 & 213.97 & 34.35 & $1,129.63$ \\
\hline 55 & 148.54 & 93.75 & 549.39 & 88.31 & 213.97 & 34.35 & $1,128.31$ \\
\hline 60 & 148.54 & 93.75 & 551.57 & 88.31 & 213.97 & 34.35 & $1,130.49$ \\
\hline 65 & 148.54 & 93.75 & 556.72 & 88.31 & 213.97 & 34.35 & $1,135.64$ \\
\hline 70 & 148.54 & 93.75 & 564.45 & 88.31 & 213.97 & 34.35 & $1,143.37$ \\
\hline
\end{tabular}

The results of the calculated private car operating costs in varied average speed and annual mileage on Perintis Kemerdekaan road section are presented in Table 9.

Table 9. VOC Recapitulation of Private Cars on Perintis Kemerdekaan road section

\begin{tabular}{|c|c|c|c|c|c|c|c|c|c|}
\hline \multirow{2}{*}{$\begin{array}{c}\text { Vehicle } \\
\text { Average } \\
\text { Speed } \\
(\mathbf{k m} / \text { hour })\end{array}$} & \multicolumn{4}{|c|}{ VOC Value (Rp/km) } & \multirow{2}{*}{$\begin{array}{c}\text { Length } \\
\text { of } \\
\text { Road } \\
\text { Sec } \\
(\mathbf{k m})\end{array}$} & \multicolumn{4}{|c|}{ Total VOC Value (Rp) } \\
\hline & 6,000 & 12,000 & 18,000 & 24,000 & & 6,000 & 12,000 & 18,000 & 24,000 \\
\hline 15 & $2.157,76$ & $1.673,17$ & $1,511.64$ & $1,430.74$ & 11,8 & 25,462 & 19,743 & 17,837 & 16,883 \\
\hline 20 & $2.034,96$ & $1.550,37$ & $1,388.84$ & $1,307.94$ & 11,8 & 24,013 & 18,294 & 16,388 & 15,434 \\
\hline 25 & $1.964,14$ & $1.479,55$ & $1,318.02$ & $1,237.12$ & 11,8 & 23,177 & 17,459 & 15,553 & 14,598 \\
\hline 30 & $1.919,92$ & $1.435,33$ & $1,273.80$ & $1,192.90$ & 11,8 & 22,655 & 16,937 & 15,031 & 14,076 \\
\hline 35 & $1.891,39$ & $1.406,80$ & $1,245.27$ & $1,164.37$ & 11,8 & 22,318 & 16,600 & 14,694 & 13,740 \\
\hline 40 & $1.873,13$ & $1.388,54$ & $1,227.01$ & $1,146.11$ & 11,8 & 22,103 & 16,385 & 14,479 & 13,524 \\
\hline 45 & $1.862,11$ & $1.377,52$ & $1,215.99$ & $1,135.23$ & 11,8 & 21,973 & 16,255 & 14,349 & 13,396 \\
\hline 50 & $1.856,51$ & $1.371,92$ & $1,210.39$ & $1,129.63$ & 11,8 & 21,907 & 16,189 & 14,283 & 13,330 \\
\hline 55 & $1.855,19$ & $1.370,6$ & $1,209.07$ & $1,128.31$ & 11,8 & 21,891 & 16,173 & 14,267 & 13,314 \\
\hline 60 & $1.857,37$ & $1.372,78$ & $1,211.25$ & $1,130.49$ & 11,8 & 21,917 & 16,199 & 14,293 & 13,340 \\
\hline 65 & $1.862,52$ & $1.377,93$ & $1,216.40$ & $1,135.64$ & 11,8 & 21,978 & 16,260 & 14,354 & 13,401 \\
\hline 70 & $1.870,25$ & $1.385,66$ & $1,224.13$ & $1,143.37$ & 11,8 & 22,069 & 16,351 & 14,445 & 13,492 \\
\hline
\end{tabular}

Table 9 explains the relationship between average speed and annual mileage as follows:

1. Analysis of the Relationship of Average Speed and Annual Mileage:

a. The lower the average speed of the trip, the greater the cost of VOC, for example; an average speed of $15 \mathrm{~km} / \mathrm{hr}$ with an annual mileage of $6,000 \mathrm{~km} /$ year compared to an annual mileage of $18,000 \mathrm{~km} /$ year

b. The lower the average speed, the greater the VOC value at the same annual mileage, for example: Speed of $15 \mathrm{~km} / \mathrm{h}$ compared to the speed of $25 \mathrm{~km} /$ hour at annual mileage: (Rp. 2,157.76 and Rp. 2,034.96) as seen in the table

2. The above analysis explains that the higher congestion leads to a lower average speed causing a higher VOC value. 
The calculation of Vehicle Operating Costs (BOK) on the Sutami Toll road is analogous to calculations on the Perintis Kemerdekaan Road Section. With an average speed taken: a speed of $60 \mathrm{~km} /$ hour; $65 \mathrm{~km}$ / hour; $70 \mathrm{~km} /$ hour; $80 \mathrm{~km} /$ hour; $85 \mathrm{~km}$ / hour; $90 \mathrm{~km} /$ hour; $95 \mathrm{~km} /$ hour and $100 \mathrm{~km} /$ hour. The results of the calculation are as follows:

For annual mileage (d) 6,000 km and average speed (V) $60 \mathrm{~km} / \mathrm{h}$

VOC $=$ depreciation + tax + fuel costs + lubricant costs + Spareparts costs + Tire

costs

$=594.17+375+551.57+88.31+213.97+34.35$

$=$ Rp. $1,857.37 / \mathrm{km}$

VOC for mileage (d) $6,000 \mathrm{~km}$ and average speed (v) $60 \mathrm{~km} / \mathrm{h}$ with the length of Reformasi Toll Road to the airport 5 -junctions of $7 \mathrm{~km}$, the VOC value is:

VOC Reformasi Toll Road to the airport 5-junctions:

$=$ Rp. $1,857.37$ x $7 \mathrm{~km}$

$=$ Rp. 13,001

Table 10. VOC Recapitulation of Private Cars on Sutami Toll Road

\begin{tabular}{|c|c|c|c|c|c|c|c|c|c|}
\hline \multirow{2}{*}{$\begin{array}{c}\text { Vehicle } \\
\text { Average } \\
\text { Speed } \\
\text { (km/hour) }\end{array}$} & \multicolumn{4}{|c|}{ VOC Value (Rp/km) } & \multirow{2}{*}{$\begin{array}{c}\text { Length } \\
\text { of } \\
\text { Road } \\
\text { Sec } \\
(\mathbf{k m}) \\
\end{array}$} & \multicolumn{4}{|c|}{ Total VOC Value (Rp) } \\
\hline & 6,000 & 12,000 & 18,000 & 24,000 & & 6,000 & 12,000 & 18,000 & 24,000 \\
\hline 60 & $1,857.37$ & $1,372.78$ & $1,211.25$ & $1,130.49$ & 7 & 13,002 & $\begin{array}{l}9,609 \\
\end{array}$ & 8,479 & 7,913 \\
\hline 65 & $1,862.52$ & $1,377.93$ & $1,216.40$ & $1,135.64$ & 7 & 13,038 & 9,646 & 8,515 & 7,949 \\
\hline 70 & $1,870.25$ & $1,385.66$ & $1,224.13$ & $1,143.37$ & 7 & 13,092 & 9,700 & 8,569 & 8,004 \\
\hline 75 & $1,880.30$ & $1,395.71$ & $1,234.18$ & $1,153.42$ & 7 & 13,162 & 9,770 & 8,639 & 8,074 \\
\hline 80 & $1,892.45$ & $1,407.86$ & $1,246.33$ & $1,165.57$ & 7 & 13,247 & 9,855 & 8,724 & 8,159 \\
\hline 85 & $1,906.53$ & $1,421.94$ & $1,260.41$ & $1,179.66$ & 7 & 13,346 & 9,954 & 8,823 & 8,258 \\
\hline 90 & $1,922.44$ & $1,437.85$ & $1,276.32$ & $1,195.56$ & 7 & 13,457 & 10,065 & 8,934 & 8,369 \\
\hline 95 & $1,940.05$ & $1,455.46$ & $1,293.93$ & $1,213.18$ & 7 & 13,580 & 10,188 & 9,058 & 8,492 \\
\hline 100 & $1,959.32$ & $1,474.73$ & $1,313.20$ & $1,232.44$ & 7 & 13,715 & 10,323 & 9,192 & 8,627 \\
\hline
\end{tabular}

Table 11. Comparison of VOC Value between Perintis Kemerdekaan Road Section and Sutami Toll Road

\begin{tabular}{|l|c|c|c|}
\hline \multicolumn{1}{|c|}{ Road Section } & $\begin{array}{c}\text { VOC Value } \\
(\mathbf{R p})\end{array}$ & Toll Tarif & $\begin{array}{c}\text { Total VOC } \\
(\mathbf{R p})\end{array}$ \\
\hline $\begin{array}{l}\text { Perintis } \\
\text { Kemerdekaan }\end{array}$ & 25,462 & - & 25,462 \\
\hline Sutami Toll & 13,002 & 12,000 & 25,500 \\
\hline
\end{tabular}

\section{CONCLUSION}

- Vehicle Operating Costs (VOC) travelling to the City Center, through the Non-Toll Road Section are Rp. 25,462, - at a distance of 6,000 km / year), compared to Rp 13,000 through Sutami Toll Road Section at a distance of $6,000 \mathrm{~km} /$ year

- The travel costs between the two alternative sections are relatively the same, however, in terms of the value of time and energy, the toll road gives more benefit for travelers heading to the center of Makassar City.

However, non-toll roads have social benefits that need further reviews to determine the benefits of road users in the future, it is necessary to develop criteria for social surplus called socio-economic user surplus'. A procedure made by a social cost benefit analysis must be 
complemented by the application of equity weights, to demonstrate the expected allocative efficiency and distribution efficiency.

\section{ACKNOWLEDGEMENT}

This paper was completed due to various assistance. Therefore, the author would like to thank the Research Institute and Resources of Universitas Muslim Indonesia, Directorate General of Higher Education, lecturers and discussion partners both in campus and outside campus, and the publisher on the attention, support and synergy fostered during this writing process of this paper. Need improvement, input, suggestions, or recommendations from all parties are expected for this paper.

\section{REFERENCES}

[1] Mogens Fosgerau, 2015, The valuation of travel time variability, International Transport Forum, Technical University of Denmark Kongens Lyngby Denmark

[2] Harahap, Sofyan,2004. Management Control System, Pustaka Quantum, Jakarta

[3] Derrick Hang, Daniel Mc Fadden, Kenneth Train, and Ken Wise, 2016, Is Vehicle Depreciation a Component of Marginal Travel Cost?, Journal of Transport Economics and Policy, Volume 50, Part 2, May

[4] Yuriy. Sigidov, Maria S. Rybyantseva, Alexandr A. Adamenko, Elena A. Yarushkina, 2016, Methodological Aspects of Depreciation as an Economic Category, International Journal of Economics and Financial Issues, 6(S1) 88-95

[5] Khisty, C. Jotin \& B. Kent Lall, 2003. Transportation Engineering: An Introduction, Prentice Hall International, Inc, New Jersey

[6] Anonymous, 2005, Calculation of Vehicle Operating Costs, Ministry of Public Works, Jakarta

[7] Adel Gohari, Nasir Matori, Khamaruzaman Wan Yusof, Iraj Toloue, and Kin Cho Myint, 2018, Effects of the Fuel Price Increase on the Operating Cost of Freight Transport Vehicles, published by EDP Sciences, Malaysia 